\title{
Simvastatin inhibits tissue factor and plasminogen activator inhibitor-1 expression of glomerular mesangial cells in hypercholesterolemic rabbits
}

\author{
Jiali $\mathrm{WEI}^{1}$, Chunyang $\mathrm{MA}^{2}$ and Xiaomeng $\mathrm{WANG}^{3}$ \\ ${ }^{1}$ Department of Nephrology, The Second Xiangya Hospital of Central South University, Middle Ren-Min Road 86, Changsha, Hunan \\ 410011; ${ }^{2}$ Department of Neurology, The Affiliated Hospital of Hainan Medical College, Longhua Road, Haikou, Hainan 510008; and \\ ${ }^{3}$ Department of Pharmacology, Hainan Medical College, Longhua Road, Haikou, Hainan 510008, PR China
}

(Received 26 April 2006; and accepted 12 June 2006)

\begin{abstract}
Tissue factor (TF) and plasminogen activator inhibitor-1 (PAI-1) activity and/or expression are upregulated in hypercholesterolemia. Despite extensive research on anti-thrombotic effect of statins, little is known about their effects on TF and PAI-1 expression in glomerular mesangial cells under hypercholesterolemic condition. Male rabbits were fed on either normal or high-cholesterol diet for 8 weeks. Then cholesterol-fed rabbits were randomly assigned to simvastatin or starch. At the end of 12 weeks, glomerular mesangial cells were collected. The concentrations of TF and PAI-1 mRNA were detected by RT-PCR. The plasma activities of TF and PAI-1 were determined with enzyme linked immunosorbent assay (ELISA) and chromogenic substrate method, respectively. The atherogenic diet caused a consistent increase in serum concentrations of total cholesterol (TC) and serum triglyceride $(\mathrm{TG})(\mathrm{p}<0.05)$, increased TF and PAI-1 mRNA expression in glomerular mesangial cells and plasma activities as compared to the normal diet $(\mathrm{p}<0.01)$. Four-week simvastatin treatment resulted in significant decrease of mesangial TF and PAI-1 mRNA $(p<0.01)$, and also of the plasma activities of TF $(\mathrm{p}<0.05)$ and PAI-1 $(\mathrm{p}<0.01)$. These results suggest that simvastatin might protect kidney from the formation of microthrombus under hypercholesterolemic condition and might be a possible pathogenesis of obesity-related glomerulopathy.
\end{abstract}

Lipid abnormalities often accompany and exacerbate renal disease $(11,16,54)$. Hypercholesterolemia is considered as an independent risk factor for renal injury (45). Previous reports show that even a short exposure to diet-induced hypercholesterolemia is associated with an increase in oxidative stress, formation of oxidized low-density lipoprotein (ox-LDL) and renal inflammation $(4,8)$. There is a close relationship among hypercholesterolemia, coagulation, fibrinolysis and glomerular damage. Glomerular fi-

Address correspondence to: Chunyang Ma, MD Department of Neurology, The Affiliated Hospital of Hainan Medical College, Longhua Road, Haikou, Hainan 510008, PR China

Tel: +86-898-66746796

E-mail: cyma323@yahoo.com.cn brin deposits and capillary microthrombi are histopathological hallmarks in many inflammatory kidney diseases (18). Fibrin may exert detrimental effects by direct cytotoxicity, by altering glomerular haemodynamics or by attracting leukocytes.

The coagulation and fibrinolytic systems are two separate but reciprocally linked enzyme cascades that regulate the formation and breakdown of fibrin. Tissue factor (TF), a membrane-anchored glycoprotein, plays an important role in promoting coagulation and thrombosis (42). TF initiates blood coagulation by forming a complex with circulating factors VII and VIIa (14). It is reported that the activation of TF is associated with renal insufficiency (37), experimental and human crescentic glomerulonephritis $(10,18)$, renal injury after ischemia and reperfusion $(36,53)$, interstitial fibrosis (56) and 
diabetic nephropathy (51). Plasminogen activator inhibitor-1 (PAI-1) is a $50 \mathrm{kDa}$ glycoprotein member of the serine protease inhibitor (SERPIN) family and is the major physiological inhibitor of tissue plasminogen activator (tPA) and urokinase-like plasminogen activator (UPA). The protease-inhibitory actions of PAI- 1 extend beyond fibrinolysis, and include modulation of extracellular matrix (ECM) turnover, cell migration and activation of several pro-enzymes and latent growth factors. Normal human kidneys do not express PAI-1 but PAI-1 is overexpressed in renal pathologic conditions including thrombotic microangiopathy, proliferative and crescentic glomerulonephritis, diabetic nephropathy, and chronic allograft nephropathy $(13,15,28,49$, 50). PAI-1 gene deficiency attenuates transforming growth factor-beta1 (TGF-beta1)-induced kidney disease, decreasing both glomerular and interstitial ECM deposition (25).

Statins, reversible inhibitors of the microsomal enzyme hydroxymethylglutaryl-coenzyme A (HMG$\mathrm{CoA}$ ) reductase which converts HMG-CoA to mevalonate, an early rate-limiting step in cholesterol biosynthesis, include atorvastatin, cerivastatin, fluvastatin, lovastatin, pravastatin, simvastatin, pitavastatin and rosuvastatin. Treatment of hyperlipidaemia with statins has led to a significant reduction in major cardiovascular events in humans $(5,21)$. Recent evidences suggest that even in the absence of cholesterol lowering, therapeutic benefits can be achieved in hypercholesterolemia due to the direct tissue effects of statins on upregulation of endothelial nitric oxide (NO) synthase (eNOS) with increased bioavailability of $\mathrm{NO}$, decreased cellular proliferation, and/or decreased oxidative stress $(35,58)$. Alterations in these pathways are often involved in renal disease progression, and the findings in vitro and vivo suggest that statins can provide protection against kidney diseases characterized by inflammation and/or enhanced proliferation of epithelial and mesangial cells (7). The renoprotective effects of statins have also been reported in ischemia-reperfusion injury (23), subtotal renal ablation (29), puromycin-induced nephrosis (19), and unilateral ureteral obstruction (40).

In addition, statins diminish procoagulant activity, which is observed at different stages of the coagulation cascade, including TF activity, conversion of prothrombin to thrombin and thrombin activity. Statins also reduce fibrinogen levels and stimulate fibrinolysis by altering the levels and activities of tPA and PAI-1 (26). Despite extensive research on antithrombotic effect of statins, little is known about their effects on TF and PAI-1 expression in glomerular mesangial cells under hypercholesterolemic condition. In this study, we used simvastatin, the methylated form of lovastatin, which competes with HMG-CoA for HMG-CoA reductase after being hydrolyzed.

\section{MATEIALS AND METHODS}

Animal experimental protocol and the diet. All animal experiments were conducted in accordance with the guidelines of animal ethical committee for animal experimentation in China. Fifteen male New Zealand rabbits (2-3 months old, weight 2000 $2300 \mathrm{~g}$ ) were provided by a breeder (Hainan Medical College, China) and individually housed in airconditioned room equipped with laminar flow. They were randomly divided into normal diet group (control group, $\mathrm{n}=5)$ and high-cholesterol diet group ( $1 \%$ cholesterol, $8.5 \%$ coconut oil, $7.5 \%$ protein, $n=10$ ) for 8 week. Then cholesterol-fed rabbits were randomly assigned to simvastatin (Merck \& Co., Inc., USA) (simvastatin group, $\mathrm{n}=5$ ) or starch (starch group, $\mathrm{n}=5$ ) at $30 \mathrm{mg} / \mathrm{kg} /$ day. Starch was used as the vehicle control for simvastatin, and was administered as a diet admixture. Simvastatin was prepared by mixing the drug with plain chow. Chow $(\approx$ 5-10 g) containing the dose of the drug was administered daily by adding it to a small chow dispenser that made chow pellets available and ensured the ingestion of the entire dose. Afterwards, drug-free high-cholesterol chow was available to the animals. Feeding was restricted to $120 \mathrm{~g} /$ day. At the end of 12 weeks of the experiment, all rabbits were sacrificed by an overdose of pentobarbital ( $4^{\text {th }}$ Pharmacological Factory, Shanghai, China). The kidneys were removed for the following experiments.

Isolation and identification of glomerular mesangial cells. Rabbit glomerular mesangial cells were prepared by a modification of the method of Lovett et al. (31). Glomerular cells collected as described above were incubated in phosphate buffered saline (pH 7.4) containing $0.1 \%$ gentamicin solution (Sigma), $1 \%$ antibiotic antimycotic (Invitrogen), and $0.5 \%$ collagenase (Sigma), at $37^{\circ} \mathrm{C}$ for half an hour to remove epithelial cells, and were vortexed every 10 min during the incubation, leaving the glomerular cores containing mesangial and endothelial cells. The cores were diluted in $1.5 \mathrm{~mL}$ RPMI 1640 medium (Gibco-BRL, USA) plus hydroxyethyl piperazineethanesulfonic acid (HEPES) (Sigma) per kidney, containing $0.1 \%$ gentamicin solution, $1 \%$ 
antibiotic antimycotic, $0.5 \%$ insulin-transferring solution, and $20 \%$ fetal bovine serum (Gibco-BRL), conditions that favor growth of mesangial cells. Cells were incubated at $37^{\circ} \mathrm{C}$ in a humidified atmosphere of $95 \%$ air- $5 \% \mathrm{CO}_{2}$. Cell viability was assessed by standard dye exclusion techniques, using $0.1 \%$ trypan blue. Mesangial cells were identified by the following criteria. Mesangial cells were stained positive for intracellular cytoskeletal fibrils of actin and smooth muscle cell-specific myosin (indicative of contractile cells), desmin, and vimentin and negative for cytokeratin and factor VIII antigens. Morphologically, the mesangial cells had an elongated and stellate or spindle-shaped morphology. Mesangial cells isolated by this procedure were homogenous and were used in all studies between passages 3-8. Before experiment, mesangial cells were cultured in 6-well plates at a density of $1 \times$ $10^{6}$ cells $/ \mathrm{mL}$.

Plasma activity of TF and PAI-1. Blood was collected from heart at the end of 12 weeks of the experiment. The plasma TF antigen assay was quantified by enzyme-linked immunosorbent assay (ELISA) (American Diagnostic) as described by Almus et al. (2). TF concentrations were determined by measuring absorbance at $450 \mathrm{~nm}$. The plasma PAI-1 activities were performed by chromogenic activity kit (Shanghai TaiYang Biotechnology, China). PAI-1 activity was assayed spectrophotometrically (44). One arbitrary unit (AU) was defined as the amount of PAI-1 activity that inhibited 1 IU of tPA.

RNA extraction and reverse transcription-polymerase chain reaction (RT-PCR). Total RNA of equivalence glomerular mesangial cells from three groups was isolated by using TRIzol reagent (Gibco-BRL) according to the manufacturer's instructions. RNA samples were dissolved in DEPC-treated water and the RNA concentration in each sample was determined spectrophotometrically. Equal amounts of RNA were analyzed for TF, PAI-1, glyceraldehydes-3-phosphate dehydrogenase (GAPDH) mRNA concentrations by quantitative reverse transcription-polymerase chain reaction (RT-PCR). The sequences of the sense and antisense primers used for amplification were as follows: TF 5'AAGCAGTGATTCCCTCTCG-3' and 5'-AACA CAGCATTGGCAGCAG-3' (1); PAI-1 5'-ATTGCT GCCCCTTATGAAAA-3' and 5'-GCCAAGGTCTT GGAGACAGA-3', GAPDH (internal control) 5'GGAGCCAAAAGGGTCATC-3' and 5'-CCAGT GAGTTTCCCGTTC-3' (1). PCR cycle for TF (254 bp) and GAPDH (346 bp) consisted of denaturing at $94^{\circ} \mathrm{C}$ for $50 \mathrm{~s}$, annealing at $58^{\circ} \mathrm{C}$ for $50 \mathrm{~s}$, and elongation at $72^{\circ} \mathrm{C}$ for $60 \mathrm{~s}$, conducted for $40 \mathrm{cy}-$ cles. PCR cycle for PAI-1 (596 bp) and GAPDH (346 bp) consisted of denaturing at $94^{\circ} \mathrm{C}$ for $50 \mathrm{~s}$, annealing at $55^{\circ} \mathrm{C}$ for $50 \mathrm{~s}$, and elongation at $72^{\circ} \mathrm{C}$ for $60 \mathrm{~s}$, conducted for 37 cycles. Those PCR products were electrophoresed on $1.5 \%$ agarose gel. Densitometric measurements were made, and the relative density (normalized by the amount of internal control) was given.

Statistical analysis. Results are expressed as mean \pm S.D. Differences between groups were evaluated by the Student's unpaired/paired two-tailed t-test. Statistically significant differences between groups were reported when $p \leq 0.05$.

\section{RESULTS}

\section{Serum TC and TG concentrations}

At the beginning of the experiment, the mean TC and $\mathrm{TG}$ concentrations $(\mathrm{mmol} / \mathrm{L})$ in the three groups had no statistical differences. Compared with the control group, the TC and TG concentrations in the starch and simvastatin group both increased significantly at the 8 th and 12 th weeks $(p<0.05)$. Simvastatin added to the cholesterol-rich diet decreased serum TC $(p<0.01$ vs. starch group or pretreatment), and did not influence serum TG (Table 1).

Table 1 Serum TC and TG concentrations at the baseline, 8th week and 12th week (mmol/L)

\begin{tabular}{lccccccc}
\hline \multirow{2}{*}{ Groups } & \multirow{2}{*}{$\mathrm{n}$} & \multicolumn{3}{c}{ TC } & \multicolumn{3}{c}{ TG } \\
\cline { 3 - 8 } & & Baseline & 8th & 12th & Baseline & 8th & 12th \\
\hline Control & 5 & $1.02 \pm 0.39$ & $1.07 \pm 0.42$ & $1.21 \pm 0.54$ & $0.92 \pm 0.53$ & $0.91 \pm 0.41$ & $1.08 \pm 0.32$ \\
Starch & 5 & $1.12 \pm 0.53$ & $22.15 \pm 0.21^{*}$ & $25.43 \pm 1.59^{*}$ & $0.78 \pm 0.36$ & $2.08 \pm 0.38^{*}$ & $2.01 \pm 0.25^{*}$ \\
Sivastatin & 5 & $0.98 \pm 0.38$ & $23.27 \pm 0.18^{*}$ & $17.25 \pm 1.63^{\#}$ & $0.89 \pm 0.34$ & $2.11 \pm 0.31^{*}$ & $1.92 \pm 0.69^{*}$ \\
\hline
\end{tabular}

$\mathrm{n}$ indicates number of animals; values are mean \pm S.D.

$* p<0.05$ vs. control group or baseline.

${ }^{\#} p<0.01$ vs. starch group or pretreatment. 
Table 2 Plasma activity of TF and PAl-1

\begin{tabular}{llcc}
\hline Groups & $\mathrm{n}$ & TF antigen $(\mathrm{ng} / \mathrm{L})$ & PAI- 1 activity $\left(\times 10^{3} \mathrm{AU} / \mathrm{L}\right)$ \\
\hline Control & 5 & $48.1 \pm 9.2$ & $8.5 \pm 1.2$ \\
Starch & 5 & $84.7 \pm 21.5^{*}$ & $17.9 \pm 2.3^{* *}$ \\
Simvastatin & 5 & $58.6 \pm 10.9$ & $10.6 \pm 1.5$ \\
\hline
\end{tabular}

$\mathrm{n}$ indicates number of animals; values are mean \pm S.D.

$* p<0.05$ vs. control group or simvastatin group.

$* * p<0.01$ vs. control group or simvastatin group.

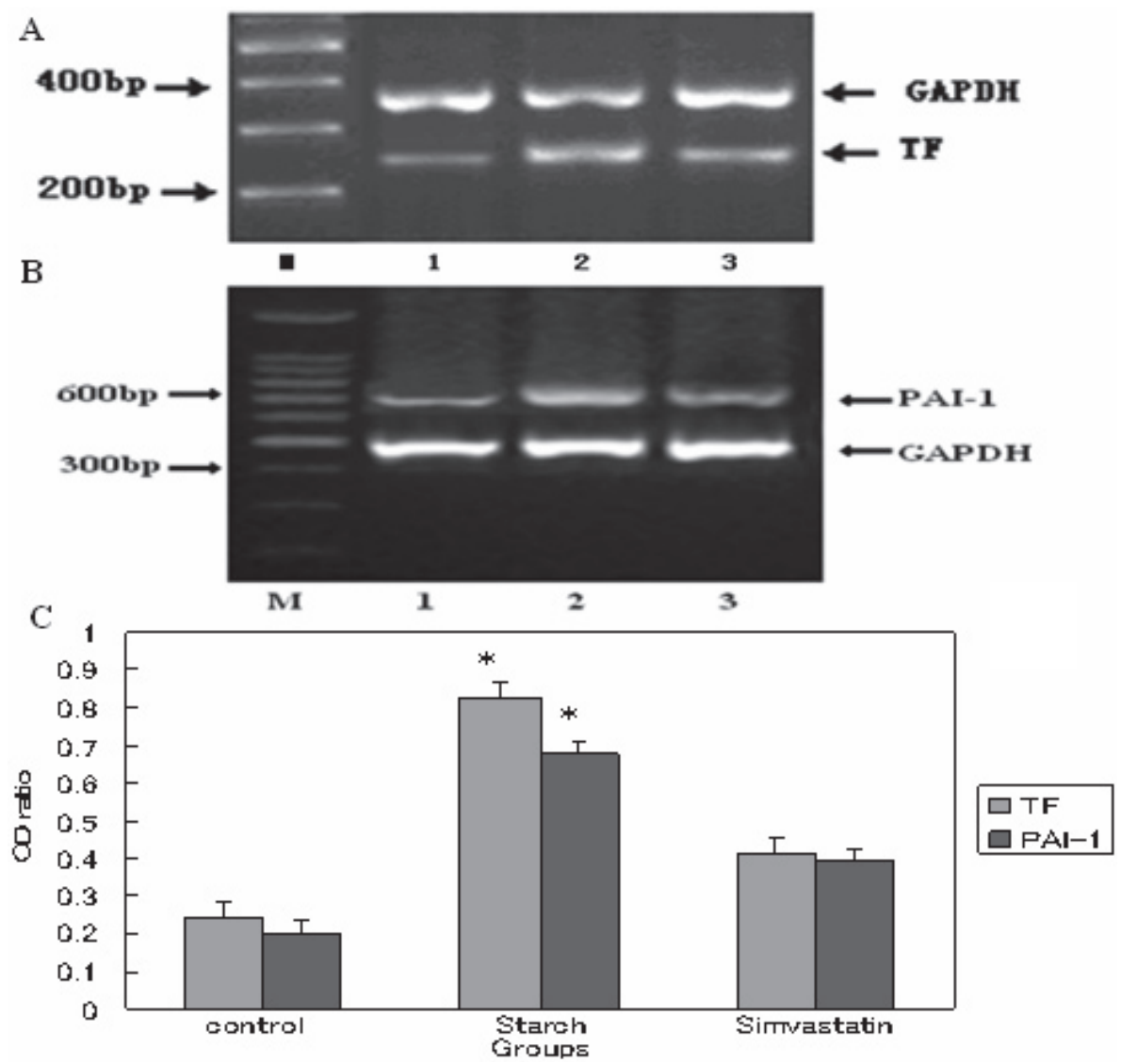

Fig. 1 mRNA expression of TF and PAI-1 in glomerular mesangial cells from control, starch, and simvastatin groups. Control indicates normal diet group; starch and simvastatin indicates hypercholesterolemic starch- or simvastatin-treated groups, respectively. A RT-PCR analysis of TF mRNA expression (upper bands: GAPDH mRNA, 346 bp; lower bands: TF mRNA, $254 \mathrm{bp}$ ) B RT-PCR analysis of PAl-1 mRNA expression (upper bands: PAl-1 mRNA, 596 bp; lower bands: GAPDH mRNA,346 bp); M: Marker, lane 1: normal diet group, lane 2: hypercholesterolemic starch-treated group, lane 3: hypercholesterolemic simvastatin-treated group. $C$ determination of relative signal intensity of TF and PAl-1 expression. Bar graph represents quantification of TF/GAPDH or PAI-1/ GAPDH mRNA signals of 3 to 4 reproductions of independent experiment. For each group, $\mathrm{n}=5$, mean $\pm \mathrm{SD}$. ${ }^{*} p<0.01$ vs. control group or simvastatin group.

\section{Plasma activities of TF and PAI-1}

The plasma activities of TF $(84.7 \pm 21.5 \mathrm{ng} / \mathrm{L})$ and PAI-1 $\left(17.9 \pm 2.3 \times 10^{3} \mathrm{AU} / \mathrm{L}\right)$ in high-cholesterol diet group were higher than those of normal diet group $(48.1 \pm 9.2 \mathrm{ng} / \mathrm{L}, p<0.05$; and $8.5 \pm 1.2 \times$ $\left.10^{3} \mathrm{AU} / \mathrm{L}, p<0.01\right)$. Four-week simvastatin treatment resulted in significant decrease of the plasma activity of TF $(58.6 \pm 10.9 \mathrm{ng} / \mathrm{L}, p<0.05)$ and PAI-1 $\left.(10.6 \pm 1.5) \times 10^{3} \mathrm{AU} / \mathrm{L}, p<0.01\right)$ compared with the high-cholesterol diet group (Table 2).

TF and PAI-1 mRNA concentrations in glomerular mesangial cells

Experiments were performed to compare the con- 
centration of gene expression in glomerular mesangial cells between control and starch rabbits. TF and PAI-1 mRNA concentrations in glomerular mesangial cells from starch group were $0.826 \pm 0.043$ and $0.667 \pm 0.032$, respectively, which significantly increased when compared with their normal counterparts $(0.241 \pm 0.011$ and $0.203 \pm 0.021$, respectively) $(p<0.01)$. Four-week simvastatin treatment resulted in significant decrease of TF $(0.412 \pm 0.025$, $p<0.01)$ and PAI-1 mRNA $(0.395 \pm 0.018, p<0.01)$ (Fig. 1).

\section{DISCUSSION}

Prothrombotic states occur in numerous human and experimental renal diseases and many evidences indicate that coagulation activation is linked to glomerular injury (24). Presence of glomerular fibrin deposits, capillary microthrombi and complete glomerular capillary occlusion are histological hallmarks of procoagulatory activity (18). Hypercholesterolemia is often accompanied by coagulation activation. Growing evidence indicate the role of hypercholesterolemia as an important risk factor for renal disease progression $(9,11,16,22,54)$. Hypercholesterolemia can impair both the function and structure of many types of vascular beds, and even at early stage, hypercholesterolemia alters vasomotor regulation in both large vessels and microcirculation (41). In addition, hypercholesterolemia may induce renal cortical neovascularization (4) and may accelerate renal vascular, glomerular, and tubular damage (8).

Our study revealed that TF and PAI-1 mRNA in glomerular mesangial cells and their plasma activity were increased on hypercholesterolemic rabbits, indicating that TF and PAI-1 participate in the pathogenesis of early renal injury in hypercholesterolemia. It has been reported that the coagulation process proceeded on mesangial cells as the result of increased expression of endogenous factor $\mathrm{V}$ on its cell surface in cooperation with exogenous factor $\mathrm{Xa}$ (47). It is demonstrated that TF and PAI-1 gene transcriptions in mesangial cells are activated by inflammatory cytokines $(12,27,38)$ and hypercholesterolemia is associated with inflammation (33), so the activation of TF and PAI-1 in glomerular mesangial cells of hypercholesterolemic rabbits might be related to the stimulation by inflammatory cytokines. Lang D et al. (27) revealed that inflammatory mediators up-regulate $\mathrm{TF}$ expression in mesangial cell by a protein kinase $\mathrm{C}$ (PKC)-dependent pathway whereas protein kinase $\mathrm{A}$ (PKA) can serve as a negative feed-back link. Induction of monocytic TF expression by endotoxin is mediated by the activation of transcription factors such as activator protein-1 (AP-1) and NF-kappaB. Both these signaling pathways are modulated by peroxisome proliferator-activated receptor-alpha (PPAR-alpha) (43).Though, monocytes/macrophages are generally believed to be the major source of $\operatorname{TF}(3,17,39)$ and endothelial PAI-1 seems to be primarily responsible for PAI-1 levels in plasma (30), our results suggested that TF and PAI-1 secretion by glomerular mesangial cells might partly account for the obesity-related glomerulopathy and the increased secretion of TF and PAI-1 in circulation.

Statins are often used in the treatment of obesity/ diabetes mellitus patients with dyslipidemia. Some of their observed benefits exceeded the degree of lipid lowering $(6,58)$, suggesting that statins have direct, lipid-lowering-independent cardiovascular effects $(21,55)$. Furthermore, previous studies have demonstrated that lipid-lowering doses of statins blunted renal insufficiency in a variety of experimental models of advanced renal disease (46), in association with a marked decrease in both blood pressure and plasma cholesterol $(7,48)$. Several studies have shown that statins exert a favorable influence on concentrations of TF and PAI-1 $(34,52)$. In vitro, pitavastatin, a novel, fully synthetic statin, markedly decreased the expression of TF in human monocytes, PAI-1 and TPA in human aortic smooth muscle cells and human umbilical vein endothelial cells (34). In vivo, simvastatin treatment significantly lowered plasma levels of matrix metalloproteinases (MMP-9), TF and PAI-1 in hypercholesterolemic and type 2 diabetes mellitus patients $(32,52)$. In our study, four-week simvastatin treatment resulted in significant decrease of TF and PAI-1 mRNA in glomerular mesangial cells. The plasma activity of TF and PAI-1 also decreased significantly. The reduction of TF and PAI-1 antigen levels in hypercholesterolemia by simvastatin may contribute to the protection of statins against thrombotic synthesis in circulation and renal glomeruli.

The regulatory mechanism by which statins suppress TF and PAI-1 mRNA expression remains unclear. Cellular mechanisms, beyond reduced cholesterol synthesis, may underlie statin's vasculoprotective effect observed clinically. Statins reduce synthesis of cholesterol and metabolites of mevalonate used in posttranslational prenylation of proteins. Although the function of these prenyl modifications is not clearly understood, many prenylated proteins play important roles in the regulation of cell growth, 
cell secretion, and signal transduction. Recently statins have been shown to inhibit PAI-1 expression by monocytes, smooth muscle cells and endothelial cells, an effect that is completely prevented by supplementation of the cells with mevalonate $(20,57)$.

In summary, TF and PAI-1 mRNA expression and plasma activities increased in glomerular mesangial cells of hypercholesterolemic rabbits. Simvastatin reduced glomerular TF and PAI-1 expression and the plasma activities, suggesting that simvastatin treatment reduces thrombosis risk in the kidney, which may protect kidney from the formation of microthrombus and fibrosis under hypercholesterolemia. However, further study should be performed to validate the mechanism of these effects.

\section{REFERENCES}

1. Aikawa M, Voglic SJ, Sugiyama S, Rabkin E, Taubman MB, Fallon JT and Libby P (1999) Dietary lipid lowering reduces tissue factor expression in rabbit atheroma. Circulation 100, $1215-1222$.

2. Almus FE, Mohan Rao LV, Pendurthi UR, Quattrochi L and Rapaport SI (1991) Mechanism for diminished tissue factor expression by endothelial cells cultured with heparin binding growth factor-1 and heparin. Blood 77, 1256-1262.

3. Badimon JJ, Zaman A, Helft G, Fayad Z and Fuster V (1999) Acute coronary syndromes: pathophysiology and preventive priorities. Thromb Haemost 82, 997-1004.

4. Bentley MD, Rodriguez-Porcel M, Lerman A, Sarefor MH, Romero JC, Pelaez LI, Grande JP, Ritman EL and Lerman LO (2002) Enhanced renal cortical vascularization in experimental hypercholesterolemia. Kidney Int 61, 1056-1063.

5. Bonetti PO, Lerman LO, Napoli C and Lerman A (2003) Statin effects beyond lipid lowering - are they clinically relevant? Eur Heart $J$ 24, 225-248.

6. Bonetti PO, Wilson SH, Rodriguez-Porcel M, Holmes DR Jr, Lerman LO and Lerman A (2002) Simvastatin preserves myocardial perfusion and coronary microvascular permeability in experimental hypercholesterolemia independent of lipid lowering. J Am Coll Cardiol 40, 546-554.

7. Buemi M, Senatore M, Corica F, Aloisi C, Romeo A, Cavallaro E, Floccari F, Tramontana D and Frisina N (2002) Statins and progressive renal disease. Med Res Rev 22, 7684.

8. Chade AR, Rodriguez-Porcel M, Grande JP, Krier JD, Lerman A, Romero JC, Napoli C and Lerman LO (2002) Distinct renal injury in early atherosclerosis and renovascular disease. Circulation 6, 1165-1171.

9. Crook ED, Thallapureddy A, Migdal S, Flack JM, Greene EL, Salahudeen A, Tucker JK and Taylor HA Jr (2003) Lipid abnormalities and renal disease: Is dyslipidemia a predictor of progression of renal disease? Am J Med Sci 325, 340-348.

10. Cunningham MA, Ono T, Hewitson TD, Tipping PG, Becker GJ and Holdsworth SR (1999) Tissue factor pathway inhibitor expression in human crescentic glomerulonephritis. Kidney Int 55, 1311-1318.

11. Diamond JR (1991) Effect of lipid abnormalities on the progression of renal damage. Analogous pathobiologic mechanisms in glomerulosclerosis and atherosclerosis. Kidney Int 39, S29-S34.
12. Eberhardt W, Beck KF and Pfeilschifter J (2002) Cytokineinduced expression of tPA is differentially modulated by NO and ROS in rat mesangial cells. Kidney Int 61, 20-30.

13. Eddy AA (2002) Plasminogen activator inhibitor-1 and the kidney. Am J Physiol Renal Physiol 283, F209-F220.

14. Edgington TS, Mackman N, Brand K and Ruf W (1991) The structural biology of expression and function of tissue factor. Thromb Haemost 6, 67-79.

15. Fogo AB (2000) The role of angiotensin II and plasminogen activator-inhibitor-1 in progressive glomerulosclerosis. $\mathrm{Am} \mathrm{J}$ Kidney Dis 35, 179-188.

16. Fried LF, Orchard TJ and Kasiske BL (2001) Effect of lipid reduction on the progression of renal disease. a meta-analysis. Kidney Int 59, 260-269.

17. Giesen PL, Rauch U, Bohrmann B, Kling D, Roque M and Fallon JT, Badimon JJ, Himber J, Riederer MA and Nemerson Y (1999) Blood-borne tissue factor: another view of thrombosis. Proc Natl Acad Sci USA 96, 2311-2315.

18. Grandaliano G, Gesualdo L, Ranieri E, Monno R and Schena FP (2000) Tissue factor, plasminogen activator inhibitor-1, and thrombin receptor expression in human crescentic glomerulonephritis. Am J Kidney Dis 35, 726-738.

19. Harris KP, Purkerson ML, Yates J and Klahr S (1990) Lovastatin ameliorates the development of glomerulosclerosis and uremia in experimental nephrotic syndrome. Am J Kidney Dis 15, 6-23.

20. Haslinger B, Kleemann R, Toet KH and Kooistra T (2003) Simvastatin suppresses tissue factor expression and increases fibrinolytic activity in tumor necrosis factor-alpha-activated human peritoneal mesothelial cells. Kidney Int 63, 20652074.

21. Heart Protection Study Collaborative Group (2002) MRC/ BHF Heart Protection Study of cholesterol lowering with simvastatin in 20,536 high-risk individuals: a randomised placebo- controlled trial. Lancet 60, 7-22.

22. Hsu CY, Bates DW, Kuperman GJ and Curhan GC (2000) Diabetes, hemoglobin $\mathrm{A}(1 \mathrm{c})$, cholesterol, and the risk of moderate chronic renal insufficiency in an ambulatory population. Am J Kidney Dis 36, 272-281.

23. Joyce M, Kelly C, Winter D, Chen G, Leahy A and Bouchier-Hayes D (2001) Pravastatin, a 3-hydroxy-3-methylglutaryl coenzyme A reductase inhibitor, attenuates renal injury in an experimental model of ischemia-reperfusion. J Surg Res 101, 79-84.

24. Kanfer A (1989) Role of coagulation in glomerular injury. Toxicol Lett 46, 83-92.

25. Krag S, Danielsen CG, Garmeliet P, Nyengaard J and Wogensen L (2005) Plasminogen activator inhibitor-1 gene deficiency attenuates TGF-beta1-induced kidney disease. Kidney Int 68, 2651-2666.

26. Krysiak R, Okopien B and Herman Z (2003) Effects of HMG-CoA reductase inhibitors on coagulation and fibrinolysis processes. Drugs 63, 1821-1854.

27. Lang D, Terstesse M, Dohle F, Bangen P, Banas B, Pauels HG and Heidenreich S (2002) Protein kinase C (PKC) dependent induction of tissue factor (TF) by mesangial cells in response to inflammatory mediators and release during apoptosis. Br J Pharmacol 137, 1116-1124.

28. Lee HB and Ha H (2005) Plasminogen activator inhibitor-1 and diabetic nephropathy. Nephrology 10, S11-13.

29. Lee SK, Jin SY, Han DC, Hwang SD and Lee HB (1993) Effects of delayed treatment with enalapril and/or lovastatin on the progression of glomerulosclerosis in 5/6 nephrectomized rats. Nephrol Dial Transplant 8, 1338-1343. 
30. Loskutoff DJ, Sawdey M, Keeton M and Schneiderman J (1993) Regulation of PAI-1 gene expression in vivo. Thromb Haemost 70, 135-137.

31. Lovett DH, Sterzel RB, Kashgarian M and Ryan JL (1983) Proteinase activity produced in vitro by cells of glomerular mesangium. Kidney Int 23, 342-349.

32. Ludwig S, Dharmalingam S, Erickson-Nesmith S, Ren S, Zhu F, Ma GM, Zhao R, Fenton JW 2nd, Ofosu FA, Velthuis HT, van Mierlo G and Shen GX (2005) Impact of simvastatin on hemostatic and fibrinolytic regulators in Type 2 diabetes mellitus. Diabetes Res Clin Pract 70, 110-118.

33. Lyon CJ, Law RE and Hsueh WA (2003) Minireview: adiposity, inflammation, and atherogenesis. Endocrinology 144, 2195-2200.

34. Markle RA, Han J, Summers BD, Yokoyama T, Hajjar KA, Hajjar DP, Gotto AM Jr and Nicholson AC (2003) Pitavastatin alters the expression of thrombotic and fibrinolytic proteins in human vascular cells. $J$ Cell Biochem 90, 23-32.

35. Maron DJ, Fazio S and Linton MF (2000) Current perspectives on statins. Circulation 101, 207-213.

36. Matsuyama M, Yoshimura R, Akioka K, Okamoto M, Ushigome H, Kadotani Y, Nakatani T and Yoshimura N (2003) Tissue factor antisense oligonucleotides prevent renal ischemia-reperfusion injury. Transplantation 76, 786-791.

37. Mercier E, Branger B, Vecina F, Al-Sabadani B, Berlan J, Dauzat M, Fourcade J and Gris JC (2001) Tissue factor coagulation pathway and blood cells activation state in renal insufficiency. Hematol $J$ 2, 18-25.

38. Meulders Q, He CJ, Adida C, Peraldi MN, Schleuning WD, Sraer JD and Rondeau E (1992) Tumor necrosis factor- $\alpha$ increases antifibrinolytic activity of cultured human mesangial cells. Kidney Int 42, 327-334.

39. Moons AHM, Levi M and Peters RJG (2002) Tissue factor and coronary heart disease. Cardiovasc Res 53, 313-325.

40. Moriyama T, Kawada N, Nagatoya K, Takeji M, Horio M, Ando A, Imai E and Hori M (2001) Fluvastatin suppresses oxidative stress and fibrosis in the interstitium of mouse kidneys with unilateral ureteral obstruction. Kidney Int 59, 2095-2103.

41. Napoli C and Lerman LO (2001) Involvement of oxidationsensitive mechanisms in the cardiovascular effects of hypercholesterolemia. Mayo Clin Proc 76, 619-631.

42. Nemerson Y (1998) Tissue factor and hemostasis. Blood 71, $1-8$.

43. Neve BP, Corseaux D, Chinetti G, Zawadzki C, Fruchart JC, Duriez P, Staels B and Jude B (2001) PPAR $\alpha$ agonists inhibit tissue factor expression in human monocytes and macrophages. Circulation 103, 207-212.

44. Nordt TK, Sawa H, Fujii S and Sobel BE (1995) Induction plasminogen activator inhibitor type-1 (PAI-1) by proinsulin and insulin in vivo. Circulation 91, 764-770.

45. Oda H and Keane WF (1999) Recent advances in statins and the kidney. Kidney Int Suppl 71, S2-S5.

46. O’Donnell MP, Kasiske BL, Kim Y, Schmitz PG and Keane WF (1993) Lovastatin retards the progression of established glomerular disease in obese Zucker rats. Am J Kidney Dis
22, 83-89.

47. Ono T, Liu N, Kasuno K, Kusano H, Nogaki F, Kamata T, Suyama K, Muso E and Sasayama S (2001) Coagulation process proceeds on cultured human mesangial cells via expression of factor V. Kidney Int 60, 1009-1017.

48. Park JK, Muller DN, Mervaala EM, Dechend R, Fiebeler A, Schmidt F, Bieringer M, Schafer O, Lindschau C, Schneider W, Ganten D, Luft FC and Haller H (2000) Cerivastatin prevents angiotensin II-induced renal injury independent of blood pressure- and cholesterol-lowering effects. Kidney Int 58, 1420-1430.

49. Paukesakon P, Revelo MP, Marcantoni C and Fogo AB (2002) Microangiopathic injury and augmented PAI-1 in human diabetic nephropathy. Kidney Int 61, 2142-2148.

50. Revelo MP, Federspiel C, Helderman H and Fogo AB (2005) Chronic allograft nephropathy: expression and localization of PAI-1 and PPAR-gamma. Nephrol Dial Transplant 20, 28122819.

51. Sommeijer DW, Florquin S, Hoedemaker I, Timmerman JJ, Reitsma PH and Ten Cate H (2005) Renal tissue factor expression is increased in streptozotocin-induced diabetic mice. Nephron Exp Nephrol 101, e86-e94.

52. Son JW, Koh KK, Ahn JY, Jin DK, Park GS, Kim DS and Shin EK (2003) Effects of statin on plaque stability and thrombogenicity in hypercholesterolemic patients with coronary artery disease. Int $J$ Cardiol $\mathbf{8 8}, 77-82$.

53. Ushigome H, Sano H, Okamoto M, Kadotani Y, Nakamura K, Akioka K, Yoshimura R, Ohmori Y and Yoshimura N (2002) The role of tissue factor in renal ischemic reperfusion injury of the rat. J Surg Res 102, 102-109.

54. Vazquez-Perez S, Aragoncillo P, de Las Heras N, NavarroCid J, Cediel E, Sanz-Rosa D, Ruilope LM, Diaz C, Hernandez G, Lahera V and Cachofeiro V (2001) Atorvastatin prevents glomerulosclerosis and renal endothelial dysfunction in hypercholesterolaemic rabbits. Nephrol Dial Transplant 16, 40-44.

55. Wassmann S, Laufs U, Baumer AT, Muller K, Ahlbory K, Linz W, Itter G, Rosen R, Bohm M and Nickenig G (2001) HMG-CoA reductase inhibitors improve endothelial dysfunction in normocholesterolemic hypertension via reduced production of reactive oxygen species. Hypertension 37, 1450 1457.

56. Wendt T, Zhang YM, Bierhaus A, Kriegsmann J, Deng Y, Waldherr R, Teske T, Luther T, Funfstuck R and Nawroth PP (1995) Tissue factor expression in an animal model of hydronephrosis. Nephrol Dial Transplant 10, 1820-1828.

57. Wiesbauer F, Kaun C, Zorn G, Maurer G, Huber K and Wojta J (2002) HMG CoA reductase inhibitors affect the fibrinolytic system of human vascular cells in vitro: a comparative study using different statins. Br J Pharmacol 135, 284-292.

58. Wilson SH, Simari RD, Best PJ, Peterson TE, Lerman LO, Aviram M, Nath KA, Holmes DR Jr and Lerman A (2001) Simvastatin preserves coronary endothelial function in hypercholesterolemia in the absence of lipid lowering. Arterioscler Thromb Vasc Biol 21, 122-128. 